\title{
Pestalozzijeva zamisel vzgoje
}

Nadja Dobnik

\begin{abstract}
Ob dvestopetdesetletnici rojstva Johanna Heinricha Pestalozzija (1746-1827) znova obujamo njegovo zamisel vzgoje, katere osnovno poslanstvo je, da omogoči človeku dostojno življenje, in je danes prav tako aktualna kot v njegovem času.
\end{abstract}

Pestalozzijeva dela so dokazala svoj pomen, saj so preživela svoj čas. Iz njih črpajo domala vsi, ki se ukvarjajo z vzgojo. Ker je bil Pestalozzijev čas bolj posvečen vzgoji in izobraževanju otrok, se njegovo ime še danes povezuje zlasti s šolskim sistemom in vzgojo otrok. Strokovnjaki so doslej premalo poznali velik pomen, ki ga imajo njegova spoznanja tudi za izobraževanje odraslih in andragoško teorijo. Zato jim ob dvestopetdesetletnici rojstva Johanna Heinricha Pestalozzija posvečamo delček zaslužene pozornosti. Pestalozzi je bil velik humanist in pomen njegovih idej v času, ko je človek spet bolj cenjen, narašča.

\section{C̆lovekova pravica do vzgoje in dostojnega življenja}

Zaradi globoke vere v človeka in brezmejne predanosti pedagoškemu delu ostaja Pestalozzi eden od stebrov razmišljanja o pomenu vzgoje in izobraževanja.

Njegovo prepričanje, da ima vsak človek pravico do vzgoje in izobrazbe ter da mu mora biti omogočeno človeka dostojno življenje, je danes na žalost prav tako aktualno, kot je bilo v tedanjem času.

Prav neverjetno je, kako lahko ob vdiranju računalniške tehnologije v vse plasti življenja prepoznamo enako stisko preprostega človeka, ki je zaradi neprimerne izobrazbe in neprilagodljivosti odrinjen na družbeni rob.

$\mathrm{V}$ podobnem položaju je bilo na prehodu v kapitalizem kmečko prebivalstvo, saj se je v novih družbenih razmerah znašlo brez pravic in možnosti odločanja.

Prav ogorčenje zaradi velikih družbenih razlik, predvsem pa zaradi brezizhodnega položaja tistega dela prebivalstva, ki se zaradi neprimerne izobrazbe ni bil zmožen prilagoditi in uveljaviti niti svojih osnovnih človekovih pravic, je bilo temeljno gibalo Pestalozzijevega razmišljanja in raziskovanja. Danes pušča razpadajoča industrija za seboj množico nemočnih, neizobraženih delavcev, ki si bodo zaradi funkcionalne nepismenosti le težko sami pomagali.

Ogorčenje se je pri Pestalozziju razvilo v globoko prepričanje o tem, da le primerna vzgoja in izobrazba lahko pomagata človeku do samostojnosti, s katero bo kljub pritiskom in družbenim spremembam mogel ohraniti integriteto in svobodo odločanja.

Čeprav se je Pestalozzi posvečal predvsem delu z otroki, ima njegovo raziskovalno delo korenine $\mathrm{v}$ izrednem posluhu za stiske in težave ljudi, ki so bili za vzgojo prikrajšani.

\section{Pestalozzi in njegov čas}

Pestalozzijev svetovni nazor se je oblikoval pod vplivom velikih družbenih sprememb, ki jih je povzročil prihod kapitalizma. Predvsem je nanj naredila globok vtis francoska revolucija,

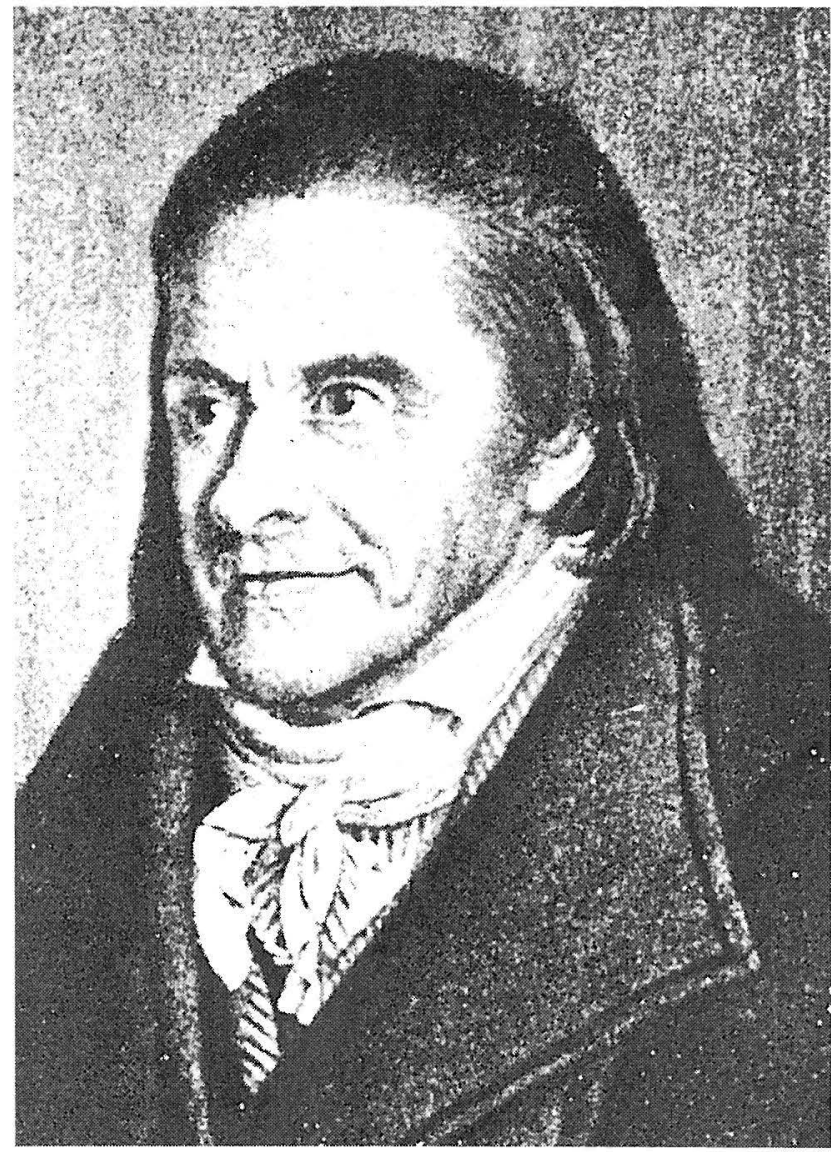

Johann Heinrich Pestalozzi

odločilen vpliv pa so imele Rousseaujeve ideje o vzgoji in Kantov nauk o »presojanju« in čutnem zaznavanju.

Na pot pravega uresničevanja svojega pedagoškega poslanstva je stopil, ko je bil že zrel mož in je imel za seboj številne grenke izkušnje. Življenjske postaje, ki so bile odločilnega pomena za razvoj njegovega pedagoškega dela, so Stanz (1799), Bourgdorg (1800-1805) in Yverdon (1805-1825).

Pestalozzijevo bivanje v Stanzu, kjer je prevzel skrb za mestno sirotišnico, je bilo kratko zaradi političnih sprememb, predvsem pa zaradi preveč naprednih vzgojnih metod, s katerimi se mestne oblasti niso strinjale.

Pod globokim vtisom izkušenj in boja z neznosnimi razmerami v sirotišnici, kjer je začel razvijati »pedagogiko srca«, utemeljeno na ljubezni in zaupanju ter uvajanju otrok v poljedelske in industrijske poklice, je kasneje nastalo Pismo iz Stanza (prvič objavljeno 1807). Predstavlja metodo moralne vzgoje, ki temelji na prepričanju o otrokovi srčni dobroti in izraža stalen poziv $\mathrm{k}$ 
premagovanju ovir in ustvarjanju. Cilj take vzgoje je ustvariti človeško skupnost, ki bo vredna same sebe in bo temeljila na velikih načelih, ki omogočajo spoznavanje in nadaljnje samouresničevanje.

Neposredno potem je učil $v$ bernskem kantonu na osnovni šoli v Burgdorfu. Tudi tu ni ostal niti eno leto. Njegovi pedagoški poskusi in metode so vidno uspevali in izzvali nasprotovanje drugih učiteljih. Zato je moral šolo zapustiti. Ob podpori burgdorfskega grofa pa je še istega leta na gradu ustanovil vzgojni zavod in učiteljski seminar. Svoje metode je nenehno izpopolnjeval. Iskal je ključ za vzgojno ravnanje vsake preproste matere. Hotel je odkriti osnovna načela o tem, kako vzgajati ljudi. Spoznanja in razmišljanja je strnil v knjigi Kako uči Gertruda svoje otroke (1801). Knjiga je kmalu postala svetovno znana in za Pestalozzijevo delo so se začeli zanimati pedagogi in misleci z vsega sveta. Kmalu so izšle še tri knjige. Kljub uspehu je vzgojno delo po štirih letih zamrlo, ker je kantonska vlada zasegla grad.

Pestalozzi se je zato leta 1805 z nekaj najzvestejšimi sodelavci preselil v Yverdon, kjer je od oblasti dobil nov grad in ga spremenil v pravi pedagoški laboratorij. Takrat je njegova slava segla že zelo daleč, obiskovali so ga znani filozofi in misleci tistega časa, za njegove ideje so zanimali tudi državniki. V začetku je imel gojence vseh stanov, vendar je bilo sčasoma, kljub naraščajočemu številu gojencev, v zavodu čedalje več otrok iz višjih stanov. V vzgojnem procesu je sodelovalo čedalje več vzgojiteljev in med njimi so nastajala nesoglasja. Pestalozzi je bil čedalje bolj obremenjen $\mathrm{z}$ upravnim delom in zato ni mogel gladiti pogostih sporov med vzgojitelji. Prav tako ni več mogel braniti svoje osrednje vzgojne zamisli in vzgojni dom je po dvajsetletnem delovanju začel propadati in nazadnje ga je moral zapreti. Poskus, da bi v istem mestu odprl sirotišnico, mu je spodletel in umaknil se je na svoje posestvo Neuhof.

Nemirni duh in prepričanje, da je odkril pomembna načela vzgoje, sta ga spodbujala k pisanju. Vplivi Rousseauaja, Kanta in Leibniza, ki so bili na začetku njegove poti še zelo vidni, so se zabrisali in izoblikovali v izvirna načela in vzgojno teorijo, ki je rastla iz bogate prakse.

Od Stanza naprej je Pestalozzi gradil svojo pedagoško teorijo. V Pismu iz Stanza je bila šele nakazana, dokončno pa jo je oblikoval leta 1801 v delu Kako Gertruda vzgaja svoje otroke in jo izpopolnjeval v Burgdorfu, predvsem pa v Yverdonu.

Teorijo podaja na elementaren način v svojih knjigah in pedagoških priročnikih, čeprav ti spisi niso dosledno sistematični. So neke vrste zapiski o izkušnjah, ki je vedno treba postavljati v določen kontekst in poiskati ravnotežje.

\section{Pedagoška teorija in Iemeljina mačela}

Pri tem, kar lahko imenujemo Pestalozzijeva pedagoška teorija, gre pravzaprav za vrsto načel, h katerim se je avtor nenehno vračal in jih nadgrajeval.

- Načelo nazornosti - Vsako učenje mora iti najprej skozi čute in mora ostati zasidrano v človekovem izkustvu. Osnovno načelo vsega spoznavanja je Pestalozzi videl v številu, obliki in besedi, njegovo povezavo $\mathrm{z}$ realnim svetom pa $\mathrm{v}$ praktičnem usposabljanju za delo, ki ustreza potrebam mladega človeka, ga zavaruje pred praznim govorjenjem, mu zagotovi razvoj in mu da demokratična načela. Praktični pouk omogoča sproščanje želje po znanju v razmerju do sveta, ki je poln izzivov.

Tako je Pestalozzi od samega začetka gradil svoj pedagoški načrt na vzgajanju otrok v stiku s poklicnim svetom, tako v obliki poljedelskih opravil (Neuhof) kot prakse pri obrtnikih (Yver- don). To je pripomoglo $\mathrm{k}$ postopnemu uvajanju otrok $\mathrm{v}$ dejavno življenje.

To Pestalozzijevo načelo se približa zakonitostim izkustvenega učenja. Izkustva so pri odraslih temelj vsega izobraževanja. C̆lovek poenoti sebe s svojim izkustvom in nazorno sprejema novo znanje iz vsakdanjih dogodkov.

- Načelo osnovne poenostavitve - Na vseh področjih izobraževanja se je redno treba vračati k preprostim, temeljnim sestavinam, v nasprotju z moderno usmeritvijo oblikovanja kompleksnih in izumetničenih pedagoških metod. Ker je cilj vzgoje in izobraževanja bolj spodbujanje naravnih sil, kot pa prenašanje znanja, omogoča vračanje $\mathrm{k}$ temeljnim sestavinam praktičnega pouka vnovično aktiviranje teh sil in potrditev znanja. Njegovi »osnovni učbeniki« so iz tega zornega kota zastavljeni kot prave zbirke vaj.

Za odrasle je značilna želja po uporabnosti znanja. Sprejemajo ga zlasti prek posameznih primerov in konkretnih razmer. Izobraževanje tudi pri odraslih sprošča in aktivira človekove potenciale.

- Načelo postopnosti in zaokroženosti - Paziti je treba, da se trudimo na vsaki stopnji svojega razvoja. Bolj kot širina je pomembna intenzivnost vloženega truda, pa čeprav je potrebno zato omejiti področje delovanja in se odpovedati takojšnjim sadovom. Cilj je manj v samem pridobivanju znanja in posameznih vzorcev vedenja in bolj v postopnem razvijanju in usklajevanju otrokovih avtonomnih sil. V tem smislu je Pestalozzi izvajal institucionalno vzgojo. Posamezne strukture (razredi, skupine, mentorstvo) so bile podrejene cilju postopnega napredovanja.

Odrasli se učijo s spoznavanjem kompleksnih, zaokroženih celot. Ko so seznanjeni s celotnim problemom, postopno prodirajo do posameznih resnic, na katere naj bi bilo znanje razdeljeno.

- Načelo aktivnosti - Otrok mora biti ves čas v središču dogajanja, pobud in ustvarjanja. Gre za telesno gibanje, ki mu je na voljo v okviru ustanove, in nenehne zahteve, da sam išče odgovore na vprašanja, ki si jih postavlja. Iz vseh zornih kotov je za Pestalozzija pedagogika gibanje.

Dejavno pridobivanje znanja je tudi v sodobni andragoški teoriji eno temeljnih načel, povzetih po Pestalozziju. Dejavno pridobljeno znanje ima svoj lasten kontekst, razlage, povezave, predstave in uporabne možnosti. Ljudje osvajajo novo znanje skokovito in ga tudi hitro prevajajo v oblike vedenja. Tudi končna ocena vzgojnih vplivov se osredini na »dejavno znanje«. Izobraževanje odraslih vrednotimo po tem, kaj je človek s svojim znanjem zmožen početi.

- Načelo osamosvojitve - Pedagoški proces ni sam sebi namen, temveč naj pomaga otroku najti način, kako bo obvladoval svoje življenje. Zato mora pedagog nenehno paziti na trenutek, ko otrok prevzame plamenico v svoje roke in samostojno in zanesljivo nadaljuje pot svojega izobraževanja. Ustanova, šolski učbeniki in pedagoška praksa pa ostanejo v službi svobodnih izbir, ki se porajajo.

Na prehodu iz industrijske družbe $\mathrm{v}$ informacijsko postaja načelo osamosvajanja človeka temeljna paradigma vsega andragoškega delovanja. Temeljni cilj izobraževanja odraslih je spreminjati ljudi tako, da bodo čedalje manj odvisni in bodo postajali samozadostnejši. Osamosvajanje je sproščanje potencialov, ki jih človek po naravi nosi v sebi.

Pestalozzi je veliko pozornosti posvečal vprašanju, kako izobraževati izobraževalce. Na vzgojo je sicer gledal kot na individualni proces oblikovanja posameznika in priznaval tekmoval- 
nost med gojenci. V skrbi, da bi preprečil prevelik egocentrizem, se je veliko ukvarjal $\mathrm{z}$ razvijanjem solidarnosti med otroki. Ta naj bi se razvijala tudi pri širjenju znanja: otrok, ki nekaj ve, ve le polovico tega, če s svojim znanjem ni pripravljen pomagati tovarišu v težavah. Tako je zasnoval mrežo medsebojnega mentorstva in zgoščene vzgojne vplive. $\mathrm{K}$ vzgoji so veliko pripomogli gojenci, ki so se med seboj učili. Pestalozzi je v svojih zavodih organiziral pravo mrežo mentorstva dijakov iz višjih razredov, ki so se ukvarjali z mlajšimi. Širši okvir so predstavljali poklicni učitelji.

\section{Sklep}

Pestalozzijeva vzgojna teorija temelji na trojnem načelu vzgoji glave, srca in rok, torej umski vzgoji, moralni vzgoji in vzgoji delovnih spretnosti. Sam je to izrazil z besedami: spoznati, hoteti, storiti. Pestalozziju gre manj za človekove zmožnosti kot za tri različne poglede na človeka: zmožnost, da se otrese zmedenih vtisov in se dokoplje do jasnih predstav; zmožnost, da uporabi svobodno voljo pri razvijanju svojih sposobnosti; tehnične sposobnosti, ki jih uporabi pri samouresničevanju.

Nadja Dobnik

predavateljica francoskega poslovnega jezika na Ekonomski fakulteti v Ljubljani

\section{Liferafure}

Houssaye J. (1995): Quinze pédagogues, Textes choisis, Paris, Ed. Armand Colin

Soetard M. (1994): Johan Heinrich Pestalozzi, v »Quinze pédagogues. Leur influence aujourd'hui«, Paris, Ed. Armand Colin

Žlebnik, L. (1955): Obča zgodovina pedagogike, Ljubljana, DZS

Žlebnik, L. (1956): Izbrani teksti pedagoških klasikov, Ljubljana, DZS

\section{GV \\ IZOBP 道VANJE}

celovito - individualno - profesionalno

TEMELJNI TEČAJ NEMŠČINE

NA DALJAVO

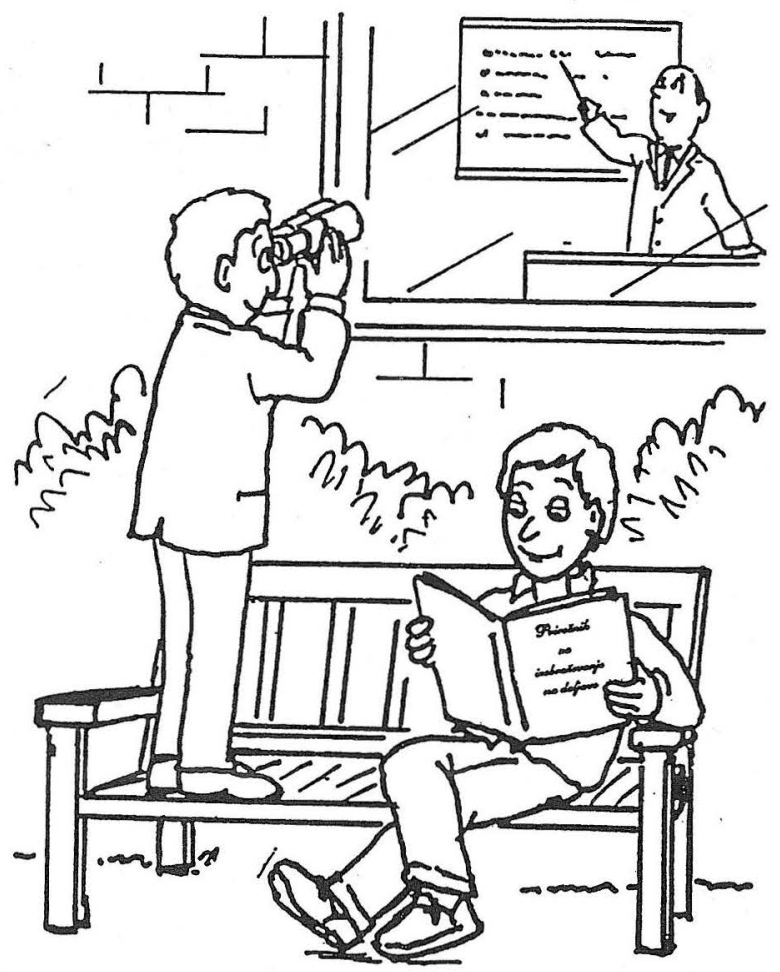

I. in II. stopnja

- učite se kadar vam najbolj ustreza

- ne izgubljate časa s prilagajanjem skupini, tempo učenja

si določate sami

- imate svojega mentorja, ki se ukvarja samo z vami

- v tečaj se lahko vpišete kadarkoli

Za tiste, ki hočejo oboje, znanje in svobodo!

Gospodarski vestnik

Založniška skupina d.d.

Dunajska 5, 1000 Ljubljana tel.: 061/133-81-26 in 133-01-27

faks: 061/132-41-87 